\title{
Green Product of Liquid Fuel from Plastic Waste by Pyrolysis at $900{ }^{\circ} \mathrm{C}$
}

\author{
Dianta Mustofa Kamal and Fuad Zainuri \\ Department of Mechanical Engineering, Politeknik Negeri Jakarta, Depok 16425, Indonesia
}

Received: September 21, 2014 / Accepted: November 05, 2014 / Published: January 31, 2015.

\begin{abstract}
Alternative treatments to convert plastic waste into fuel currently receive great attention from researchers worldwide. The objective of the research is to obtain liquid fuel from pyrolysis of waste plastics that is safe for humans as well as environment, with a heating value and fuel quality meet the standardized compliant. The method used for the research is plastic waste pyrolysis heated at $900{ }^{\circ} \mathrm{C}$, and the resulting vapor is condensed through a crossflow condenser. The method resulted in a liquid fuel with a calorific value of $46,848 \mathrm{~J} / \mathrm{g}$, which is greater than that of plastic waste processing at a temperature of $425{ }^{\circ} \mathrm{C}$ that is only $41,870 \mathrm{~J} / \mathrm{g}$. In addition, the nature of current method for treating plastic waste is considered more secure than that of plastic waste processing at the temperature of $425{ }^{\circ} \mathrm{C}$. The reason for this is the fact that the percentage of compounds that could potentially be carcinogenic (boric acid and cyclopentanone) is reduced.
\end{abstract}

Key words: Plastic waste, fuel, pyrolysis, green product.

\section{Introduction}

As the highest consumption of fossil fuels country, Indonesia consumed petroleum for approximately 1.6 million barrels per day in 2005, while in 2006, it reached 1.84 barrels per day. Other countries such as Japan and Germany equally consume only less than 1 million barrels per day [1]. In 2013, the United States produced about 30 million tons of plastic each year total, but with only about $4 \%$ are recycled [2]. In addition to producing energy, the combustion of fossil energy sources also releases gases, including $\mathrm{CO}_{2}$ (carbon dioxide), $\mathrm{NO}_{\mathrm{x}}$ (nitrogen oxides), and $\mathrm{SO}_{2}$ (sulfur dioxide), which causes air pollution [3]. So it is highly necessary to find alternative fuels to be widely used that are environmentally friendly.

Research developed at this time can be used as fuel instead of fossil fuels [4]. Previously, in 2009, Anggono [1] has conducted a research on the type of plastic waste from food packaging (Low Density

\footnotetext{
Corresponding author: Dianta Mustofa Kamal, Dr., research field: renewable energy. E-mail: dmustofa@ymail.com.
}

Polyethylene or LDPE) at a temperature of $425{ }^{\circ} \mathrm{C}$ heating, and the results show that compounds have properties such as flammable acetone and cyclopentanone (1.68\% area) [5]. In the same year, Damanhuri [6] stated that the cyclopentanone compounds were cyclic ketone compounds that potentially exist carcinogenic gas (toxic). In addition, boric acid is also harmful if it is accidentally breathed in, since it may irritate mucous membranes that showed by sore throat, coughing, and short breathing.

Basing on the background, Indonesia contributed to the decline in petroleum reserves and also the problem of energy crisis faced by the world today. Therefore, this study aimed to obtain liquid fuels resulted from pyrolysis of waste plastics that is safe for humans and environment, with a heating value and fuel quality that meet standardized-compliant.

\section{Material and Method}

Shredded plastic waste and included in the converter and heated to a temperature of $900^{\circ} \mathrm{C}$, and the resulting vapor is condensed through a crossflow condenser. 
Fuel oil is produced at the heating temperature of $900{ }^{\circ} \mathrm{C}$, and the heating value is tested using Bomb Calorimeter and testing GC (gas chromatography). Tests conducted uses the calorific value-bomb calorimeter contained in Energy Conversion Engineering Laboratory, Polytechnic of Jakarta. GC-MS (GC mass spectrometry) analysis method is used to read both spectra contained in the combined method.

GC test results if there are samples contain many compounds, which are evident from the many peaks (peak) in the GC spectra. Based on the data retention and time is already known from the literature, we know what compounds were present in the sample [7]. Next step is to incorporate the compound into the alleged mass spectroscopy instruments. This can be done because one of the uses of GC is to separate the compounds of a sample. After that, the results can be obtained from MS spectra at different charts.

\section{Result and Discussion}

Pyrolysis process starts at temperatures around $230{ }^{\circ} \mathrm{C}[8]$ and happens in the absence of oxygen for thermal decomposition of organic material $[9,17]$.

Plastic is a synthetic organic material or semi-synthetic organic materials derived from petroleum and natural gas of plastic products, resulting in PET (polyethylene terephthalate), HDPE (high density polyethylene), PVC (polyvinyl chloride), LDPE (low density polyethylene), PP (polypropylene), PS (polystyrene), polyurethane and polyphenols, generating plastic waste that consists around $50 \%-60 \%$ of polyethylene, $20 \%-30 \%$ of polypropylene, $10 \%-20 \%$ of polystyrene, and $10 \%$ of polyvinyl chloride [10, 17]. For PE (polyethylene) medium and high density polyethylene, the melting point ranges from $120{ }^{\circ} \mathrm{C}$ to $135{ }^{\circ} \mathrm{C}$. Low density polyethylene melting point ranges from $105^{\circ} \mathrm{C}$ to $115{ }^{\circ} \mathrm{C}$. HDPE is characterized by a density that exceeds or equals to $0.941 \mathrm{~g} / \mathrm{cm}^{3}$. HDPE has a low degree of the ramifications and inter-molecular [16] strength and very high tensile strength. It functions

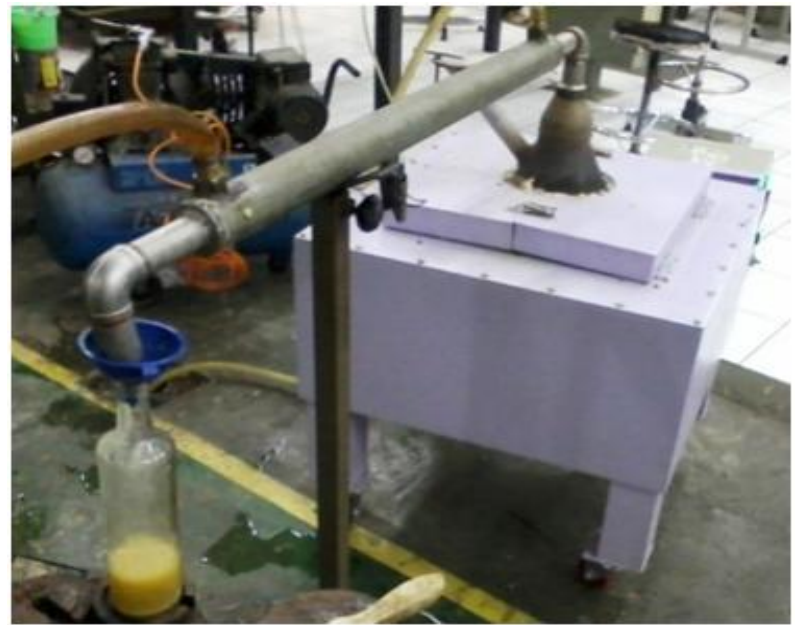

Fig. 1 Converter plastic waste into fuel.

as material for milk bottle, bottle/detergent packaging, packaging margarine, water pipes and bins. LDPE is characterized by a density from $0.910 \mathrm{~g} / \mathrm{cm}^{3}$ to 0.940 $\mathrm{g} / \mathrm{cm}^{3}$. LDPE has a high degree of the long and short chain branching, which means it will not turn into a crystalline structure. It also indicates that LDPE has a low tensile strength. LDPE can be found in the form of container since it is strong and in the form of plastic film applications, such as plastic bags and plastic wrap. LLDPE (linear LDPE) is characterized by a density between $0.915 \mathrm{~g} / \mathrm{cm}^{3}$ and $0.925 \mathrm{~g} / \mathrm{cm}^{3}$. LLDPE is a linear polymer with a short chain branching with a significant amount. LLDPE is used as material for cable wrap, toys, packaging caps, buckets, containers and pipe [15].

Sapriyanto [5] has tested a machine to convert plastic waste into fuel. The test material is $1 \mathrm{~kg}$ of plastic waste that is heated within $530{ }^{\circ} \mathrm{C}$ heating. All kinds of plastic are put into the machine. Then, within two hours, the machine produces liquid fuels as much as $300 \mathrm{~mL}$. The test shows the calorific value of the fuel is plastic waste of $10,519 \mathrm{cal} / \mathrm{g}$ or $44,040.95 \mathrm{~J} / \mathrm{g}$, equivalent to the heating value of the premium is $10,285 \mathrm{cal} / \mathrm{g}$ or $43,061.24 \mathrm{~J} / \mathrm{g}$. In the same year, Ramadhan [11] also examined the oil obtained from the pyrolysis process of waste plastic. This study uses two types of plastic as a fixed variable, namely HDPE and LDPE, using the reactor with a diameter of $20 \mathrm{~cm}$ and height of $40 \mathrm{~cm}$. Pyrolysis temperature is held at 
$250-420^{\circ} \mathrm{C}$ and the reaction time lasts for 0-60 minutes. Oil produced in the pyrolysis process can be compared to kerosene and oil is a source of valuable chemicals, such as alcohols, organic acids, ethers, ketones, aliphatic and aromatic hydrocarbons. And gas is produced in the form of $\mathrm{Co}_{\mathrm{x}}, \mathrm{NO}_{\mathrm{x}}, \mathrm{H}_{2}$ and alkanes [6, 15, 19].

Suryo [12], in his study of the properties of a mixture of waste biomass pyrolysis oil and plastic waste PP (polypropylene), tries to investigate the density, viscosity and heating value. The pyrolysis oil resulted from the research is thus used to boil water on the stove. The efficiency of pyrolysis oil stoves is also tested using standard WBT (water boiling test). The research shows the obtained oil-fired stove efficiency is best at $30 \%$ biomass composition and $70 \%$ plasticat the temperature of $400{ }^{\circ} \mathrm{C}$.

Based on the decision of the Director General of Oil and Gas in 2008, the Ministry of Energy and Mineral Resources of the Republic of Indonesia, the standards and quality (specification) of fuel, in the form of oil marketed in the country, are as follows [13, 18].

At first, pyrolysis technology is considered as an environmentally friendly method [14] since the method ultimately produces $\mathrm{CO}_{2}$ and $\mathrm{H}_{2} \mathrm{O}$, the former is a non-toxic gas. But in its development, the cyclopentanone compounds as the result of the pyrolysis of cyclic ketones can potentially turn into carcinogenic gas (toxic). In addition, boric acid, also harmful if inhaled, can cause irritation of mucous membranes accompanied by sore throat, coughing, and breathing becomes short [3]. Cyclopentanone compounds can be identified through gas chromatography $[7,15,17,19]$.

The calorific value is compared to the value obtained with the standard and quality (specification) of fuel oil type of oil that is marketed in the country (Dept. of Energy and Mineral Resources of Indonesia, 2008) [19], to meet the calorific value of fuel, standards should be above $41,870 \mathrm{~J} / \mathrm{g}$. Based on test results, the value of the heat, produced of $11,189 \mathrm{cal} / \mathrm{g}$ or 46,848 $\mathrm{J} / \mathrm{g}$, thus can meet the standard calorific value of the fuel sold in the country.

Based on the results of testing, the fuel produced at the heating temperature of $900{ }^{\circ} \mathrm{C}$ obtained levels of flammable compounds (2-propanone) increases, while potentially carcinogenic compounds (boric acid and cyclopentanone) reduced the percentage.

Table 1 Specifications of fuel oil [18].

\begin{tabular}{|c|c|c|c|c|c|c|c|}
\hline \multirow{3}{*}{ No. } & \multirow{3}{*}{ Characteristic } & \multirow{3}{*}{ Units } & \multicolumn{4}{|c|}{ Limit } & \multirow{3}{*}{$\begin{array}{l}\text { Testing } \\
\text { method } \\
\text { ASTM }\end{array}$} \\
\hline & & & \multicolumn{2}{|c|}{ Intermediete fuel oil-1 } & \multicolumn{2}{|c|}{ Intermediate fuel oil-2 } & \\
\hline & & & Min. & Marks. & Min. & Marks. & \\
\hline 1 & NilaiKalori & $\mathrm{MJ} / \mathrm{kg}$ & 41.87 & - & 41.87 & - & D 240 \\
\hline 2 & Densityat $15^{\circ} \mathrm{C}$ & $\mathrm{kg} / \mathrm{m}^{3}$ & - & 991 & - & 991 & D 1259 \\
\hline 3 & Kinematics Viscosityat $50^{\circ} \mathrm{C}$ & $\mathrm{mm}^{2} / \mathrm{dt}$ & - & 180 & - & 380 & D 445 \\
\hline 4 & Sulfur contain & $\% \mathrm{~m} / \mathrm{m}$ & - & 3.5 & - & 4.0 & D $1552 / 2622$ \\
\hline 5 & Melting point & ${ }^{\circ} \mathrm{C}$ & - & 30 & - & 40 & D 97 \\
\hline 6 & Flashing point & ${ }^{\circ} \mathrm{C}$ & 60 & - & 60 & - & D 93 \\
\hline 7 & Carbon Residual & $\% \mathrm{~m} / \mathrm{m}$ & - & 16 & - & 20 & D 189 \\
\hline 8 & Ash contain & $\% \mathrm{~m} / \mathrm{m}$ & - & - & - & 0.15 & D 482 \\
\hline 9 & Sedimen & $\% \mathrm{~m} / \mathrm{m}$ & - & - & - & 0.10 & D 473 \\
\hline 10 & Water contain & $\% \mathrm{v} / \mathrm{v}$ & - & - & - & 1.00 & D 95 \\
\hline 11 & Aluminium + silikon & $\mathrm{mg} / \mathrm{kg}$ & - & - & - & - & D 5184/AAS \\
\hline
\end{tabular}

Source: Director general SK oil \& gas, energy and mineral resources, 2008.

Table 2 Test results calorific value (1 gram mass oil plastic).

\begin{tabular}{ll}
\hline Calorific value & Unit (cal/g) \\
\hline BBM plastic & 11.189 \\
Premium & 11.245 \\
Quality Standards of Ministry of Energy in Indonesia & 10.000 \\
\hline
\end{tabular}


Testing results of GC-MS

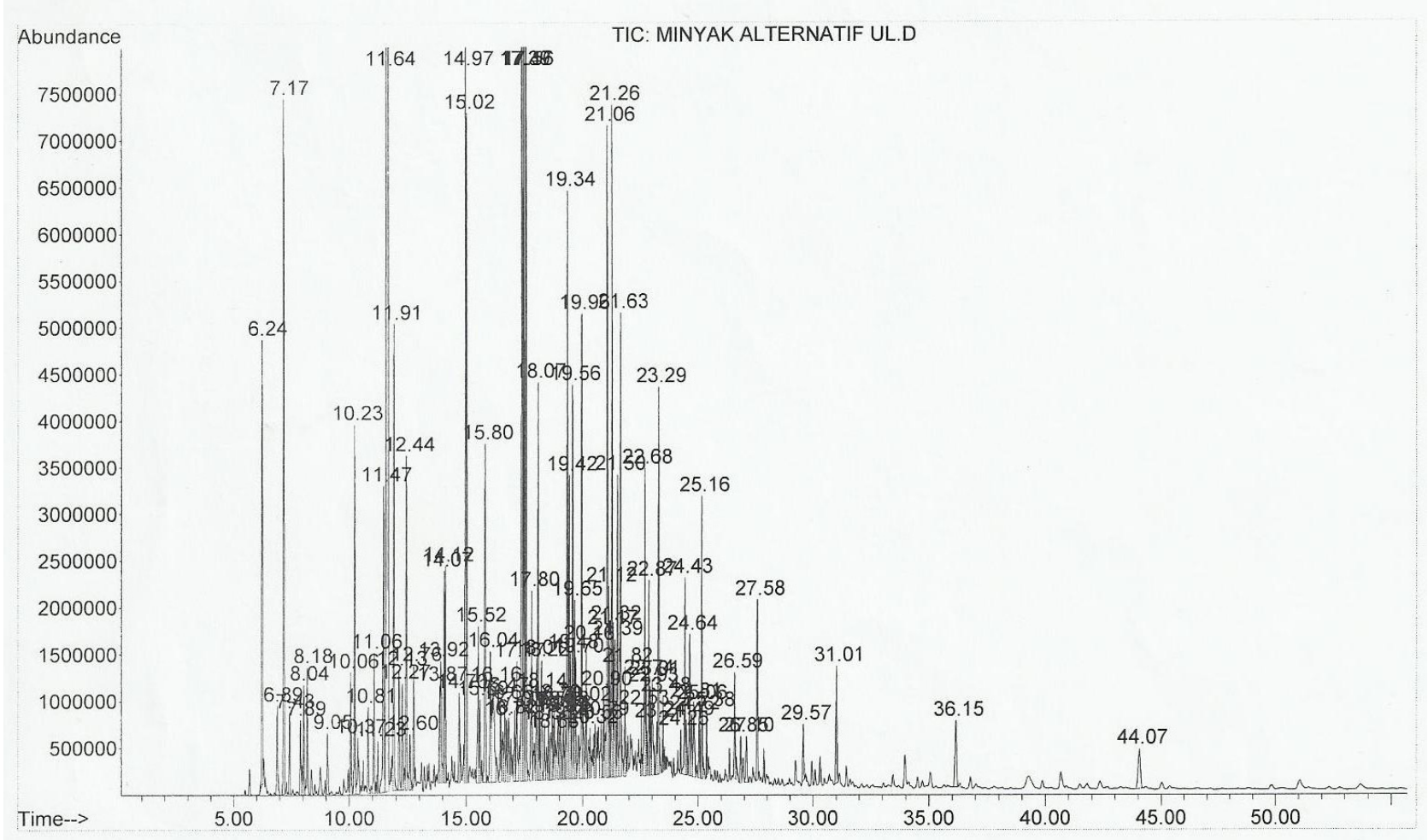

Fig. 2 Graphs the GC-MS testing fuel from plastic waste.

Table 3 Data of important compounds of liquid fuels from waste plastics.

\begin{tabular}{lllll}
\hline No. & Peak & \% Area & Expected compounds & Formula \\
\hline 1 & 1 & 64.69 & 2-propanon/acetone & $\mathrm{C}_{3} \mathrm{H}_{6} \mathrm{O}$ \\
2 & 2 & 27.08 & Boric acid & $\mathrm{H}_{3} \mathrm{BO}_{3}$ \\
3 & 3 & 0.09 & - & - \\
4 & 4 & 6.93 & Acetic acid & $\mathrm{C}_{2} \mathrm{H}_{4} \mathrm{O}_{2}$ \\
5 & 5 & 1.20 & Cyclopentanone & $\mathrm{C}_{5} \mathrm{H}_{8} \mathrm{O}$ \\
\hline
\end{tabular}

\section{Conclusion}

The processing of plastic waste at a temperature of $900{ }^{\circ} \mathrm{C}$ produces liquid fuel with calorific value of $46.848 \mathrm{~J} / \mathrm{g}$ which means that this value is greater than that of the processing of plastic waste at a temperature of $425{ }^{\circ} \mathrm{C}$ which results in the calorific value of 41.870 $\mathrm{J} / \mathrm{g}$.

Testing the fuel produced GC-MS showed that the levels of potentially carcinogenic compounds (boric acid and cyclopentanone) is reduced so that the percentage of plastic waste at a temperature of $900{ }^{\circ} \mathrm{C}$ has more secure properties than that of plastic waste processing at a temperature of $425^{\circ} \mathrm{C}$.

\section{References}

[1] Anggono. 2009. "Pyrolysis of Waste Plastics to Getting Liquid Smoke and Determination of Chemical Components and Its compiler Ability Test for Liquid Fuels." Sainsdan Terapan Kimia 3 (2): 174-82.

[2] Sarker, M., and Rashid, M. M. 2013. "Food Container Waste Plastic Conversion into Fuel." International Journal of Engineering and Applied Sciences 3 (1): 1-16.

[3] Kays, W. M., and London, A. L. 1955. Compact Heat Exchangers. Palo Alto: National Press.

[4] Abatneh, Y., and Sahu, O. 2013. "Preliminary Study on the Conversion of Different Waste Plastics into Fuel Oil." International Journal of Scientific \& Technology Research 2 (5): 226-9.

[5] Sapriyanto, A., 2011. Plastic Waste Converters Being Oil. Student Creative Program of Politeknik Negeri Jakarta, 
Indonesia.

[6] Damanhuri, E., 2009. Management of Hazardous and Toxic Materials (B3). Bandung Institut of Technology.

[7] Rodiansono, Triyono, W. T. 2007. "Preparation, Characterization and Activity Test of $\mathrm{NiMo} / \mathrm{Z}$ and $\mathrm{NiMo} / \mathrm{Z}-\mathrm{Nb}_{2} \mathrm{O}_{5}$ Catalysts for Hydro Cracking of Waste Plastic Fraction to Gasoline Fraction." Berkala MIPA 17 (2): 43-54.

[8] Kreith, F., and William, Z. B. 1980. Basic Heat Transfer. New York: Harper \& Row.

[9] Kamal, D. M., 2013. "Polytech: Conversion Machine of Plastikinto Oil Fuel with Continuous System and Reservoir Wet-Steam Oil with $20 \mathrm{~kg}$ Capacities." In Proceedings of AISC, 283-7.

[10] Sari. 2011. The Calorific Value Combustion Optimization Bio-briquettes Coal Mixed with Coconut Shell Charcoal. Sebelas Maret University, Surakarta, Indonesia.

[11] Ramadhan, A., and Munawar, A., 2011. "Plastic Waste Processing Using Pyrolysis Process into Oil." Jurnal Ilmiah Teknik Lingkungan 4 (1): 44-53.

[12] SuryoAji Wibowo, A. 2011. The Study of Characteristics of Mixed Waste Biomass Pyrolysis Oil and Waste Plastic Polypropylene (PP). Sebelas Maret University, Surakarta, Indonesia.
[13] Sarker, M., and Rashid, M. M. 2013."Mixture of LDPE, PP and PS Waste Plastics into Fuel by Thermolysis Process." International Journal of Engineering and Technology Research 1 (1): 1-16.

[14] Napitupulu, F. H. 2006. Effect of Calorific Value (Heating Value) a Planning against Fuel Fuel Boiler Room Volume Method Based Determination of Calorific Value of Fuel Required. Mechanical Engineering, North Sumatera University.

[15] Imam, M., 2005. The Nature and Characteristics of Plastic Materials and Materials Additives. Academy of Maritim, Semarang, Indonesia.

[16] Munson, B. R., Young, D. F., and dan Okiishi, T. H. 2002. Fundamentals of Fluid Mechanics, 4th ed.. Hoboken: John Wiley \& Sons.

[17] Pavia, D. L., Gary, M. L., George, S. K., and Randall, G. E. 2006. Introduction to Organic Laboratory Techniques, 4th ed. Belmont: Thomson Brooks/Cole, 797-817.

[18] Regulation of the Ministerof Environment No.13 Year 2009 regarding Standard Emissions Activity Oil and Gas Industry.

[19] Zuhra, C. F. 2003. "Refining, Processing and Using of Crude Oil." NorthSumatra University. Digitized by USU Digital Library. 